\title{
A!
}

This is an electronic reprint of the original article.

This reprint may differ from the original in pagination and typographic detail.

Hu, Rui; Ding, Wenxiu; Yan, Zheng

\section{Privacy-preserving Computation over Encrypted Vectors}

Published in:

2020 IEEE Global Communications Conference, GLOBECOM 2020 - Proceedings

DOI:

10.1109/GLOBECOM42002.2020.9322329

Published: 01/12/2020

Document Version

Peer reviewed version

Please cite the original version:

Hu, R., Ding, W., \& Yan, Z. (2020). Privacy-preserving Computation over Encrypted Vectors. In 2020 IEEE

Global Communications Conference, GLOBECOM 2020 - Proceedings [9322329] (IEEE Global

Communications Conference). IEEE. https://doi.org/10.1109/GLOBECOM42002.2020.9322329

This material is protected by copyright and other intellectual property rights, and duplication or sale of all or part of any of the repository collections is not permitted, except that material may be duplicated by you for your research use or educational purposes in electronic or print form. You must obtain permission for any other use. Electronic or print copies may not be offered, whether for sale or otherwise to anyone who is not an authorised user. 





